Images in...

\title{
Mediastinal ganglioneuroma mimicking a bronchogenic cyst
}

\author{
Frances Anne Hampson, ${ }^{1}$ Mark Slade, ${ }^{2}$ Nagmi Qureshi ${ }^{1}$ \\ ${ }^{1}$ Radiology Department, Papworth Hospital NHS Foundation Trust, Cambridge, UK; \\ 2Respiratory Medicine Department, Papworth Hospital NHS Foundation Trust, Cambridge, UK
}

Correspondence to Dr Frances Anne Hampson, fran.hampson@btopenworld.com

\section{DESCRIPTION}

A 75-year-woman with a Duke's B adenocarcinoma of the caecum underwent a staging CT examination which revealed an oval, $3.6 \times 2.5 \mathrm{~cm}$ fluid attenuation mass (18

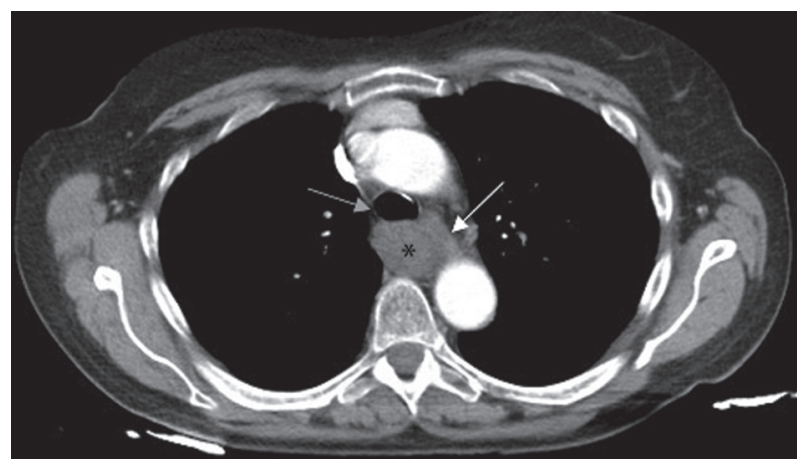

Figure 1 Axial CT image obtained following the administration of intravenous contrast medium. The image demonstrates the oval, fluid attenuation, middle mediastinal mass (black asterisk) which abuts the posterior aspect of the trachea (grey arrow) and the medial aspect of the oesophagus (white arrow).

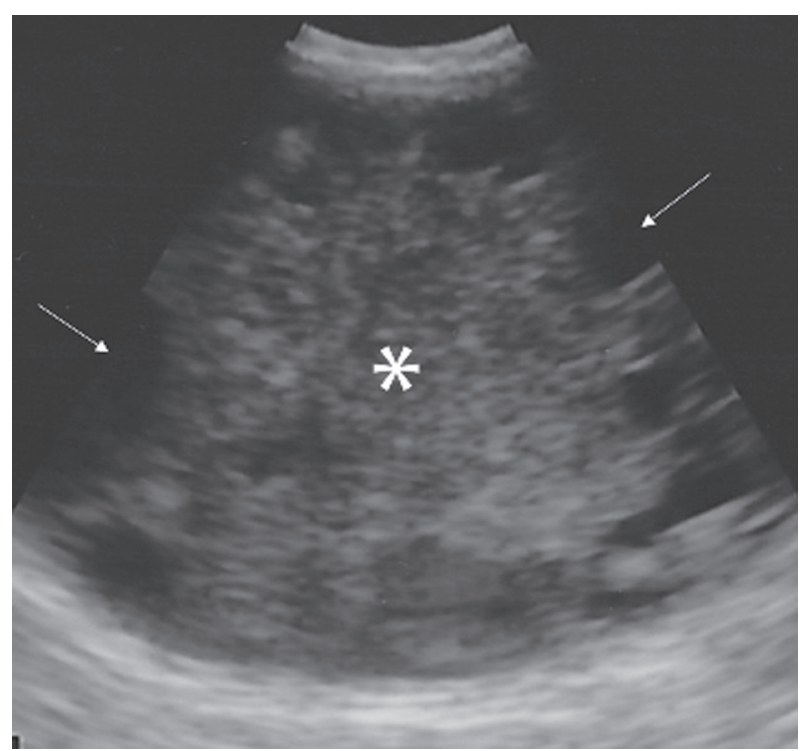

Figure 2 Endobronchial ultrasound image of the mass prior to aspiration which revealed the lesion to be predominantly solid and echogenic (white asterisk) with a minor peripheral cystic component (white arrows).
Hounsfield units) superior to the carina, posterior to the trachea and medial to the oesophagus (figure 1). She had no symptoms relating to the mediastinal mass. Radiologically the lesion was thought to be most in keeping with a bronchogenic cyst. The most likely potential differential diagnoses were considered to be an oesophageal duplication cyst, a metastatic lymph node mass or a primary oesophageal tumour. In order to establish the diagnosis and exclude the possibility of malignancy, the lesion was aspirated under endobronchial ultrasound guidance (figure 2). The aspirate contained tissue fragments composed of fine spindle-shaped Schwann cells and mature ganglion cells. There was no evidence of malignancy. Immunohistochemistry demonstrated that the spindle cells expressed S100 protein but no smooth muscle actin. There was also positive staining for CD56 and synaptophysin. There were no cytokeratin positive cells. These findings revealed the lesion to be a benign neurogenic tumour, most likely a ganglioneuroma.

Learning points

- Ganglioneuromas typically arise in the posterior mediastinum. They are an uncommon finding in the middle mediastinum.

- This case illustrates that neurogenic tumours should be considered in the differential diagnosis of a middle mediastinal mass.

- FNA (fine needle aspiration) is an excellent tool which can be used to differentiate benign from malignant mediastinal lesions. ${ }^{12}$

Competing interests None.

Patient consent Obtained.

\section{REFERENCES}

1. Domanski HA. Fine-needle aspiration of ganglioneuroma. Diagn Cytopathol 2005;32:363-6.

2. Dim DC, Nugent SL, Peng HO. Ganglioneuroma presenting as a paraesophageal mass lesion diagnosed by endoscopic ultrasound-guided fine needle aspiration cytology: a case report. Acta Cytol 2010;54:321-4. 


\section{BMJ Case Reports}

This pdf has been created automatically from the final edited text and images.

Copyright 2012 BMJ Publishing Group. All rights reserved. For permission to reuse any of this content visit http://group.bmj.com/group/rights-licensing/permissions.

BMJ Case Report Fellows may re-use this article for personal use and teaching without any further permission.

Please cite this article as follows (you will need to access the article online to obtain the date of publication).

Hampson FA, Slade M, Qureshi N. Mediastinal ganglioneuroma mimicking a bronchogenic cyst. BMJ Case Reports 2012;10.1136/bcr.07.2011.4447, Published XXX

Become a Fellow of BMJ Case Reports today and you can:

- Submit as many cases as you like

- Enjoy fast sympathetic peer review and rapid publication of accepted articles

- Access all the published articles

- Re-use any of the published material for personal use and teaching without further permission

For information on Institutional Fellowships contact consortiasales@bmjgroup.com

Visit casereports.bmj.com for more articles like this and to become a Fellow

Keep up to date with all published cases by signing up for an alert (all we need is your email address) http://casereports.bmj.com/cgi/alerts/etoc 